\title{
低カゼイン飼料にメチオニンを補足した際に おこる脂肪肝と摂食量との関係
}

\author{
野 田 克 彦 \\ 德島大学医学部栄養学科
}

\begin{abstract}
Effect of Food Intake on the Liver Lipid Content of Rats fed the Low Casein Diet Supplemented with Methionine
\end{abstract}

\author{
Katuhiko Noda \\ Department of Nutrition, School of Medicine, Tokushima University. \\ kuramoto, Tokushima
}

J. Japan. Soc. Food and Nutr. 24 (2) 89 91 (1971)

\begin{abstract}
Relationship between food intake and liver lipid content of young female rats fed an $8 \%$ casein diet supplemented with or without $0.3 \%$ of methionine was studied.

Food intake of the basal ( $8 \%$ casein only) diet group was approximately $80 \%$ of that of the methionine supplemented diet group. When rats fed the basal diet were forced to feed the basal diet as same calories as that of animals fed the methionine supplemented diet group, liver lipid content was increased. On the other hand, when food intake of rats fed the methionine supplemented diet was restricted at the amount of that of the basal diet group, liver lipid content of the methionine supplemented diet group was decreased. But in either cases, liver lipid content of the methionine supplemented diet group was higher than that of the basal diet group.

No relationship was observed between liver lipid content and plasma triglyceride level or between liver lipid content and liver glucose-6-phosphate dehydrogenase activity. Close corelation between plasma triglyceride level and plasma cholesterol level was observed.
\end{abstract}

(Received January 8, 1971)

8 ないし $9 \%$ ガインを含む飼料に $0.3 \%$ のメチオニ ソを添加して白鼠を飼育すると肝臓中に脂肪が蓄積する ことが知られておりりこれにさらにスレオニンを添加す ることで脂肪肝を防ぐことができる。この際メチオニン 添加飼料群の掑取量を減少させると, 肝蔵への脂肪の蓄 棈は少なくなる2。 またメチオニン添加による脂肪肝生 成はエチオニンによるそれとは異なるらしいことが示唆 されているが。

この報文ではカロリ一摂取量を变化させたときの肝脂 肪量および血中脂肪量などの変化について, 摂食量制限 および飼料強制投与の効果について述べる。

\section{実 験 方 法}

\section{1. 動物およひ捔料投与方法}

ウィスター系雌性白鼠の初体重 $50 \mathrm{~g}$ 前後のものを用 い, 個別ケージに入れて室温 $23 \sim 24^{\circ} \mathrm{C}$ の部屋で飼育し た。飼料として第 1 表に示寸組成の食慨を投与した。基 本飼料には蛋白源としてカゼインを $8 \%$ 含んでいる。’ チオニン添加飼料としてはしーメチオニンを0.3\%添加し, イチオニン，スレオニン添加飼料はさらにLースレオニン $0.2 \%$ 添加した。炭水化物源として蔗糖のみを用いた。 脂肪はコーンオイルを $5 \%$ ，ビタミン，ミネラルは必要 十分量与えている。

食慨没与方法は，それぞれの飼料を自由に掑取させた 実験(メチオニン, スレオニン添加飼料群は除く), 基本 飼料群と同量のメチオニン添加またはメチオニン, スレ オニン添加飼料を与える制限食の実験, および基本飼料 群にメチオニン添加飼料群が摄取したのと同量の飼料重 
Table 1. Composition of the basal, methionine supplemented, or methionine threonine supplemented diet

\begin{tabular}{lccc}
\hline \hline Components & Basal & $\begin{array}{c}\text { Diet } \\
\text { Methionine } \\
\text { Supplemented }\end{array}$ & $\begin{array}{l}\text { Methionine } \\
\text { Threonine } \\
\text { Supplemented }\end{array}$ \\
\hline Casein & 8 & 8 & 8 \\
L-Methionine & - & 0.3 & 0.3 \\
L-Threonine & - & - & 0.2 \\
Corn oil & 5 & 5 & 5 \\
Mineral Mixture* & 5 & 5 & 5 \\
Vitamin Mixture* & 0.85 & 0.85 & 0.85 \\
Choline-Cl* & 0.2 & 0.2 & 0.2 \\
Vitamin A & $2000 \mathrm{IU}$ & $2000 \mathrm{IU}$ & $2000 \mathrm{IU}$ \\
Vitamin D & $5 \mu \mathrm{g}$ & $5 \mu \mathrm{g}$ & $5 \mu \mathrm{g}$ \\
Vitamin E & $10 \mu \mathrm{g}$ & $10 \mu \mathrm{g}$ & $10 \mu \mathrm{g}$ \\
Sucrose & \multicolumn{4}{c}{ made to $100 \%$} \\
\hline \hline
\end{tabular}

* Tanabe Amino Acid Research Foundation

量になるだけの基本飼料を自由拱取の差額だけ胃管を用 いて毎日午前中に強制投与する実験を行なった。摂食量 と体重測定は毎日行なった。

\section{2. 测定方法}

1 週間それぞれの飼料で飼育したのち，動物を殺し， 肝蔵をすみやかに摘出し，科量する。その一部を切り取 って $1 \% \mathrm{KCl}$ 溶液にてホモジネートを作り,グルコース -6ーリン酸脱水素醉素 (G6PDH) 活性 ${ }^{4)}$ を測定した。残 りの肝蔵で肝脂肪量を測定した。肝脂肪量はェーテル抽 出法 (Goldfish Fat Extractor, Labo. Construction Co., Kansas City, U.S.A.)により測定し, 肝乾物重量当りの パーセントで表わした。

制限食餌の実験に拀いては, ネンブタールを用いて麻 酔をした動物から，ヘパリン処理をした注射筒を用いて 心臓採血を行ない，血清を分離し，血中トリグリセライ ド(Plasma TG) $)^{5)}$ コレステロール6)の定量を行なった。

結果

\section{1. 強制食餌の結果}

基本飼料群の掑食量は 1 日平均 $7.8 \mathrm{~g}$ であり,メチオニ
(\%)

ン添加群の提食量の約 $80 \%$ に相当する。その羑 額は，対応するそれぞれの対の鼠の提食量 1日 分の羑だけの基本飼料を少量の熱湯に溶解し， 体温程度に冷却したすのを, ポリエチレンチュ ーブを通じて胃内へ直接注入した。1 群 5 匹で スタートしたか，胃管投与により極端に食欲を 減退させたり，下㢉を起こしたるのか 2 匹あり， それを除いた結果を第 2 表に示す。基本飼料の 強制投与によって，体重增加量はわずかではあ るが上界しまた肝脂質量も明らかに增加した。 しかし体重增加量も肝脂質量も同一カロリーを 摂取しているメチオニン添加群にはおよばなか った。

\section{2. 制限食餌の結果}

メチオニン添加飼料群の提食量を基本飼料群 と同量に制限した際には，体重增加量，肝脂肪 量共にメチオニン添加飼料を自由に掑取した群 の值に比して低下したが，基本飼料を自由に摄 取した群よりなおまだ高值であった。血中トリグリセラ イドは自由摂食では両者の食慨組成のちがいによる差異 はなく、これは前の結果 ${ }^{3)}$ と同様である。制限食慨群に おいて血中トリグリセライドはむしろ低い值を示した。 スレオニン添加によっても血中トリグリセライドの增加 は認められなかったが, 肝脂質量はかなり低下していた。 血中コレステロール值も血中トリグリセライドと同様の 傾向を示した。

肝 G6PDH 活性についてはメチオニン添加飼料の自 由摂取群の方が基本飼料群より高い傾向にあったが, 制 限食にした際には基本飼料群より低い值を示し，メチオ ニン, スレオニン添加群の酵素活性が他のいずれの群の 醉素活性よりも高く, 肝脂質量との間に相関は見出され なかった。

\section{考察}

基本飼料群の肝脂質量は, メチオニン添加飼料群と同 量のカロリ一摂取の条件に批いても低く、メチオニンは カロリー出納のバランスにおいて何らかの作用を及伊し ていると考えられる。×チオニンは副堅皮質機能を促進

Table 2. Effect of forced feeding on the liver lipid content of rats fed the basal diet

\begin{tabular}{llcccc}
\hline Diets & Feeding Methods & $\begin{array}{l}\text { Number } \\
\text { of Rats }\end{array}$ & $\begin{array}{l}\text { Food } \\
\text { Intake }\end{array}$ & $\begin{array}{l}\text { Weight } \\
\text { Gain }\end{array}$ & $\begin{array}{l}\text { Liver } \\
\text { Lipids }\end{array}$ \\
\hline \multirow{3}{*}{ Basal } & & & (g/Day) & (g/Week) & $(\%)$ \\
Basal & Ad libitum & 5 & 7.8 & $3.9 \pm 2.8$ & $8.2 \pm 0.4$ \\
Methionine Supplemented & Forced feeding & 3 & 9.6 & $5.8 \pm 1.6$ & $11.1 \pm 1.8$ \\
& Ad libitum & 3 & 9.6 & $12.0 \pm 4.3$ & $17.3 \pm 0.7$ \\
\hline
\end{tabular}


Table 3. Effect of paired feeding on the liver lipid content, liver G6PDH activity and plasma lipids levels of rats fed the basal, methionine supplemented or threonine supplemented diet

\begin{tabular}{|c|c|c|c|c|c|c|c|c|}
\hline Diets & Feeding Methods & $\begin{array}{l}\text { Number } \\
\text { of Rats }\end{array}$ & $\begin{array}{l}\text { Food } \\
\text { Intake }\end{array}$ & $\begin{array}{l}\text { Weight } \\
\text { Gain }\end{array}$ & $\begin{array}{l}\text { Liver } \\
\text { Lipids }\end{array}$ & $\begin{array}{l}\text { Liver } \\
\text { G6PDH }\end{array}$ & $\begin{array}{c}\text { Plasma } \\
\text { TG }\end{array}$ & $\begin{array}{l}\text { Plasma } \\
\text { Cholesterol }\end{array}$ \\
\hline & & & (g/Day) & (g/Week) & (\%) & $\begin{array}{l}\text { ( } \mathrm{m} \mu \text { moles } \\
\text { NADPH/mg } \\
\text { protein } / \mathrm{min} . \text { ) }\end{array}$ & $(\mathrm{mg} / \mathrm{d} l)$ & $(\mathrm{mg} / \mathrm{d} l)$ \\
\hline Basal & Ad libitum & 5 & 6.1 & $3.8 \pm 2.2 \quad 1$ & 13. $2 \pm 2.3$ & $27 \pm 3$ & $65.6 \pm 3.0$ & $122 \pm 11$ \\
\hline $\begin{array}{l}\text { Methionine } \\
\text { Supplemented }\end{array}$ & Paired & 5 & 6.1 & 4. $9 \pm 3.2 \quad 1$ & $19.4 \pm 1.5$ & $24 \pm 3$ & $47.6 \pm 6.5$ & $5 \quad 98 \pm 4$ \\
\hline $\begin{array}{l}\text { Methionine } \\
\text { Threonine } \\
\text { Supplemented }\end{array}$ & Paired & 5 & 6.1 & 13. $8 \pm 3.2 \quad 1$ & 15. $5 \pm 4.2$ & $38 \pm 6$ & $51.9 \pm 5.0$ & $0 \quad 107 \pm 5$ \\
\hline $\begin{array}{l}\text { Methionine } \\
\text { Supplemented }\end{array}$ & Ad libitum & 5 & 9.4 & 16. $4 \pm 4.2 \quad 2$ & 23. $9 \pm 2.1$ & $35 \pm 5$ & $62.3 \pm 6.5$ & $5 \quad 116$ 上 8 \\
\hline
\end{tabular}

することが知られているが7)，もしメチオニンがそのよ うな機作で肝脂質量を上舁させているとすると，副腎皮 質ホルモンによる肝脂肪量への影響があるはずである。 事実吉田ら ${ }^{8)}$ (副腎摘除が肝脂肪量を低下させ, 副腎摘 出動物への副腎皮質ホルモンの投与が肝脂質量を增大さ せることを報告している。しかしながらそのような副腎 機能を促進しないシスチンによってもメチオニンと全く 同様に脂肪肝を生ずる1)ことの説明はできない。

血中トリグリセライドに打いては, 基本飼料群とメチ オニン添加群とで差はなぐ， 制限食慨にすることによ り肝脂質量が低下すると血中トリグリセライドも低下し ている。また血中コレステロール值も血中トリグリセラ イド値と全く同じ傾向を示した。このようなことからメ チオニン添加飼料群で肝からの脂肪搬出が低下して，そ れが脂肪肝を起すといら可能性はきわめて弱いと思われ る。

このようにメチオニン添加は単に摂食量を增加させる ことのみによって脂肪肝を起こしているのではなく, 何 らかの働きを含硫了ミノ酸が行ならと考えねばならな い。カゼインへのメチオニン添加は含硫アミノ酸を多量 に含む蛋白質（たとえば膵藏の内，外分泌蛋白質など） の合成を促進し，それが摄食量や脂肪合成速度に変化を 起こさせる可能性はあるかるしれない。

メチオニンと同時にスレオニンを添加することによる 脂肪肝の軽減は，同一カロリ一量を摂取している基本飼 料群やメチオニン添加飼料群と比較して(第 3 表), その 成長のよさからす推測てきるように，すはやいわゆる低
蛋白条件による影響は消隇しているのであろう。

$$
\text { 要約 }
$$

低カゼイン飼料にメチオニンを添加して起こる脂肪肝 について，掑食量との関係をしらべ次の結果を得た。

（1）基本飼料（8\%カゼインのみを含む）を投与された 白鼠の肝脂質量は, メチオニン添加飼料群と同量のカロ リー㠌取となるようにしてもメチオニン添加飼料群のそ れより低值である。

(2) 肝脂質量と血中トリグリセライドまたは肝 G6PDH 活性の間には相関が見出されない。

（3）血中トリダリセライド值と血中コレステロール值は きわめて類似した変動を示す。

\section{文献}

1) Harper, A. E.: Am. J.Clin. Nutr., 6, 242(1958)

2) Yoshida, A., Ashida, K., Harper, A.E.,: Nature, 189, 917 (1961)

3) 吉田 昭, 守時圭子, 野田克彦: 栄坫と食糧, 19, 261 (1966)

4 ) Methods in Enzymology, I, ed. by S. P. Colowick and N. O. Kaplan (1956) Academic Press, P. 323.

5) Van Handel, E.: Clin. Chem., 7, 249 (1961)

6) Pearson, S., Stern, S., Mcganack, T.H.: Anal. Chem., 25, 813 (1953)

7) Munro, H. N., Steele, M. H., Hutchison, W. C.: Nature, 199, 1182 (1963)

8) Yoshida, A., Harper, A. E.: Agr. Biol. Chem., 33, 1097 (1969)

（昭和 46 年 1 月 8 日受理） 